\title{
Macrofossil Assemblages in the Ryazanian Stage (Lower Cretaceous) of the Stratotype Region
}

\author{
Olga S. Urman ${ }^{*}$, Boris N. Shurygin ${ }^{1,2}$, Oksana S. Dzyuba1 \\ ${ }^{1}$ Trofimuk Institute of Petroleum Geology and Geophysics, Siberian Branch, Russian Academy of Sciences, Novosibirsk, Russia \\ ${ }^{2}$ Novosibirsk National Research State University, Novosibirsk, Russia \\ Email: *urmanos@ipgg.sbras.ru
}

How to cite this paper: Urman, O.S., Shurygin, B.N. and Dzyuba, O.S. (2019) Macrofossil Assemblages in the Ryazanian Stage (Lower Cretaceous) of the Stratotype Region. Open Journal of Geology, 9, 558-561. https://doi.org/10.4236/ojg.2019.910041

Received: August 15, 2019

Accepted: September 17, 2019

Published: September 20, 2019

Copyright $\odot 2019$ by author(s) and Scientific Research Publishing Inc. This work is licensed under the Creative Commons Attribution International License (CC BY 4.0).

http://creativecommons.org/licenses/by/4.0/ cc) (i) Open Access

\begin{abstract}
The stratotype region of the Ryazanian stage is located in the Oka River Basin near Ryazan, Central Russia. Since ammonites are very well studied here, we investigated other groups of macrofossils. We report a large number of bivalve genera: Arctica, Astarte, Buchia, Camptonectes, Chlamys, Ctenostreon, Entolium, Gomomya, Gresslya, Hartwellia, Lima, Meleagrinella, Modiolus, Oxytoma, and Pleuromya. The belemnites are represented by two cylindroteuthidid genera, Acroteuthis and Liobelus. In addition, brachiopods (Rhynchonellidae and Terebratulidae) and unidentifiable gastropod fragments have been revealed. The highest taxonomic diversity of macrofauna is observed in the Surites spasskensis ammonite Zone.
\end{abstract}

\section{Keywords}

Fossil Mollusks, Brachiopods, Ryazanian, Central Russia

\section{Introduction}

The problem of correlation of the Volgian and Ryazanian stages with the standard Tithonian and Berriasian stages has not yet been unambiguously solved, but it has been proven that the upper part of the Upper Volgian substage belongs to the Cretaceous System. Nevertheless, it is still justified to recognize the Volgian and Ryazanian in the vast Boreal palaeobasins, because these regional stages reflect two different periods of geologic history, primarily that of palaeobasin in the East European Platform [1]. To some extent, this is also a tribute to the traditions, according to which most of the geological documents for Boreal regions were compiled in the XX-early XXI centuries. And the Volgian-Ryazanian 
boundary is characterized by reliable bioevent markers in Boreal sections. However, it is hardly correct to treat the Volgian-Ryazanian boundary as the Jurassic-Cretaceous $(\mathrm{J}-\mathrm{K})$ boundary. The definition of the Ryazanian stage and its base largely depends on the detailed study of the stratotype region located in the Oka River Basin near Ryazan, Central Russia.

\section{A Review of New Data}

The precise stratigraphic position of fossil finds in the Ryazanian of the stratotype region is usually difficult to determine due to the highly condensed $\mathrm{J}-\mathrm{K}$ boundary sections in Central Russia, their small thicknesses and numerous sedimentation interruptions. Therefore, the stratigraphic position of the lower horizons of the Ryazanian in Central Russia is still under discussion.

The Ryazanian deposits in the Oka River Basin contain numerous shells of mollusks, especially those of bivalves, but ammonites are the best studied group in the stratotype region [2] [3]. Following Mitta [3], we recognize three ammonite zones within the Ryazanian in the Oka River Basin, namely the Riasanites rjasanensis, Surites spasskensis and Surites tzikwinianus zones. Bivalves, belemnites, gastropods as well as brachiopods are the main objects of our research.

Representatives of the genus Buchia are most abundant among bivalves. It is noteworthy that Boreal zonal scales based on Buchiidae are successfully used for the subdivision and correlation of the J-K boundary beds in Boreal regions [4]. In addition to the beds with Buchia fischeriana, a sequence of mixed assemblages from different Buchia zones is observed in the Ryazanian stage for the Oka River sections [5]. These are beds with Buchia volgensis + Buchia okensis + Buchia jasikovi, and beds with $B$. volgensis $+B$. jasikovi + Buchia tolmatschowi. In the standard Boreal biostratigraphic scale, the B. okensis Zone, the B. jasikovi Zone and the $B$. tolmatschowi Zone have been distinguished as a series of zones parallel to the $B$. volgensis Zone [4] [6] [7]. Other bivalve taxa identified from the Ryazanian on the Oka River are members of the genera Hartwellia, Lima, Pleuromya (in the Riasanites rjasanensis Zone), Arctica, Astarte, Camptonectes, Chlamys, Ctenostreon, Entolium, Gomomya, Gresslya, Hartwellia, Meleagrinella, Modiolus, Oxytoma, and Pleuromya (in the Surites spasskensis Zone).

In all studied sections, belemnites are represented by two genera, Acroteuthis and Liobelus (Cylindroteuthididae). Cylindroteuthidid belemnites are a relatively new tool for pan-Boreal correlation of the J-K boundary beds [8] [9]. Two belemnite beds can be recognized in the Ryazanian on the Oka River: an upper part of the regional beds with Liobelus russiensis and Acroteuthis mosquensis, and the beds with Acroteuthis explanatoides [5]. Belemnites are rather frequent here, especially Acroteuthis. A certain sequence in the appearance of species from the genus Acroteuthis is observed upward in the section: A. mosquensis $A$. arctica - $A$. subquadratoides - $A$. explanatoides.

In addition to cephalopods and bivalves, we found brachiopods (Rhynchonellidae and Terebratulidae) and unidentifiable gastropod fragments, all in the 
Surites spasskensis ammonite Zone. This zone is characterized by the highest taxonomic diversity of macrofauna.

\section{Conclusion}

In the Ryazanian stage of the stratotype region, the richest assemblage of macrofossils is recorded from the Subboreal Surites spasskensis ammonite Zone, which corresponds to the middle part of the Hectoroceras kochi Zone - Surites analogus Zone in the Boreal ammonite scale.

\section{Acknowledgements}

This is a contribution to the Russian PFSI (0331-2019-0004) and UNESCO/ IUGS/IGCP 679 project.

\section{Conflicts of Interest}

The authors declare no conflicts of interest regarding the publication of this paper.

\section{References}

[1] Shurygin, B.N. and Dzyuba, O.S. (2015) The Jurassic/Cretaceous Boundary in Northern Siberia and Boreal-Tethyan Correlation of the Boundary Beds. Russian Geology and Geophysics, 56, 652-662. https://doi.org/10.1016/j.rgg.2015.03.013

[2] Mitta, V.V. (2007) Ammonite Assemblages from Basal Layers of the Ryazanian Stage (Lower Cretaceous) of Central Russia. Stratigraphy and Geological Correlation, 15, 193-205. https://doi.org/10.1134/S0869593807020050

[3] Mitta, V.V. (2017) The Ryazanian (Basal Lower Cretaceous) Standard Zonation: State of Knowledge and Potential for Correlation with the Berriasian Primary Standard. Neues Jahrbuch für Geologie und Paläontologie-Abhandlungen, 286, 141-157. https://doi.org/10.1127/njgpa/2017/0691

[4] Zakharov, V.A. (1987) The Bivalve Buchia and the Jurassic-Cretaceous Boundary in the Boreal Province. Cretaceous Research, 8, 141-153. https://doi.org/10.1016/0195-6671(87)90018-8

[5] Urman, O.S., Shurygin, B.N. and Dzyuba, O.S. New Paleontological and Stratigraphic Data on the Ryazanian Regional Stage in the Oka River Sections (Central Russia). Izvestiya of Saratov University. New Series. Series: Earth Sciences. In Press.

[6] Zakharov, V.A., Bogomolov, Yu.I., Ilyina, V.I., Konstantinov, A.G., Kurushin, N.I., Lebedeva, N.K., Meledina, S.V., Nikitenko, B.L., Sobolev, E.S. and Shurygin, B.N. (1997) Boreal Zonal Standard and Biostratigraphy of the Siberian Mesozoic. Russian Geology and Geophysics, 38, 965-993.

[7] Urman, O.S., Dzyuba, O.S., Kirillova, G.L. and Shurygin, B.N. (2014) Buchia Faunas and Biostratigraphy of the Jurassic-Cretaceous Boundary Deposits in the Komsomolsk Section (Russian Far East). Russian Journal of Pacific Geology, 8, 346-359. https://doi.org/10.1134/S1819714014050066

[8] Dzyuba, O.S. (2012) Belemnites and Biostratigraphy of the Jurassic-Cretaceous Boundary Deposits of Northern East Siberia: New Data on the Nordvik Peninsula. Stratigraphy and Geological Correlation, 20, 53-72. 


\section{https://doi.org/10.1134/S0869593811060037}

[9] Dzyuba, O.S. (2013) Belemnites in the Jurassic-Cretaceous Boundary Interval of the Mauryn'ya and Yatriya River Sections, Western Siberia: Biostratigraphic Significance and Dynamics of Taxonomic Diversity. Stratigraphy and Geological Correlation, 21, 189-214. https://doi.org/10.1134/S0869593813020020 